\author{
A. A. Levina ${ }^{a}$, N. O. Tadevosyan ${ }^{a}$, S. A. Petrova ${ }^{b}$, \\ E.S. Buyanova ${ }^{a}$, M. V. Morozova ${ }^{a}$ \\ ${ }^{a}$ Ural Federal University, \\ 19 Mira St., 620002, Ekaterinburg, Russia \\ ${ }^{b}$ Institute for Metallurgy, Ural Branch of the Russian Academy of Sciences, \\ 101 Amundsen St., 620016, Ekaterinburg, Russia \\ email: anastasia.levina@urfu.ru
}

\title{
Phase formation processes and synthesis of solid solutions in $\mathrm{Ca}-\mathrm{R}-\mathrm{Nb}-\mathrm{M}-\mathrm{O}$ systems
}

During the study of the phase formation process in $\mathrm{Ca}-\mathrm{R}-\mathrm{Nb}-\mathrm{M}-0$ systems $(\mathrm{R}=\mathrm{La}, \mathrm{Bi}, \mathrm{M}=\mathrm{Mo}, \mathrm{W})$, an attempt was made to obtain single-phase compounds of $\mathrm{CaRNbMO}_{8}$ composition by the standard ceramic technique. In addition, samples based on $\mathrm{LaNbO}_{4}, \mathrm{CaWO}_{4}, \mathrm{BiNbO}_{4}$ were also synthesized by the standard ceramic technique. The phase composition of the samples was studied by XRD analysis. The electrical conductivity of the obtained solid solutions and potential composite materials was investigated by impedance spectroscopy.

Keywords: sheelite; fergusonite; solid solutions; electrical conductivity

Received: 18.02.2020. Accepted: 12.03.2020. Published: 31.03.2020.

(C) Levina A. A., Tadevosyan N. O., Petrova S. A., Buyanova E. S., Morozova M. V., 2020

\section{Introduction}

Currently, there is an active search for new materials that can be used as electrodes and electrolytes of solid oxide fuel cells, oxygen sensors and membranes of electrochemical devices. Modern technology uses well-established materials with highly symmetric (usually cubic) structure such as fluorite or perovskite, where ionic conductivity is based on the migration of oxygen vacancies [1-3]. Recently, it has been demonstrated that structures with lower symmetry achieve high oxygen ion conductivity, which is due to the presence of oxygen ions in interstitial positions in materials with both ionic and mixed conductivity [4]. Such materials include a number of complex oxides that have sheelite or fergusonite structure and correspond to the formula
$\mathrm{ABO}_{4}\left(\mathrm{~A}=\mathrm{Me}^{2+} / \mathrm{Me}^{3+}, \mathrm{B}=\mathrm{Me}^{5+} / \mathrm{Me}^{6+}\right)$ Thus, $\mathrm{LaNbO}_{4}$ is characterized by insufficiently high values of electrical conductivity (at $100{ }^{\circ} \mathrm{C} \sigma \approx 5.5 \cdot 10^{-5} \mathrm{Ohm}^{-1} \cdot \mathrm{cm}^{-1}$ ), but some solid solutions based on it show an increase in conductivity by 1-3 orders of magnitude both with an acceptor [5] and a donor doping [6].

In addition, new materials with promising characteristics can be found based on the results of studies on the preparation of complex oxide solid solutions. For example, $\mathrm{Vu}$ et al. [7] investigated the phase diagram $\mathrm{La}_{2} \mathrm{O}_{3}-\mathrm{WO}_{3}-\mathrm{Nb}_{2} \mathrm{O}_{5}$ and to date discovered and studied a new composition $\mathrm{La}_{3} \mathrm{NbWO}_{10}$, which is characterized by a relatively high oxygen conductivity due to the transport of oxygen ions. 
Deepa et al. [8] studied the system $\mathrm{Ca}-$ $\mathrm{Ce}-\mathrm{Nb}-\mathrm{M}-\mathrm{O}$ (where $\mathrm{M}=\mathrm{Mo}$ or $\mathrm{W}$ ). All samples $\mathrm{Ca}_{2} \mathrm{CeNbM}_{2} \mathrm{O}_{12}, \mathrm{CaCeNbMO}$, and $\mathrm{CaCe}_{2} \mathrm{Nb}_{2} \mathrm{MoO}_{12}$ have cubic structure with a space group (SG) I41/a. Electrical conductivity increases with increasing cerium concentration, which is due to the variable valence of cerium. Excess oxygen is released into the atmosphere upon heating, leaving electron in the lattice, which is further responsible for the conductivity of the compound [8].

Thus, the establishment of mechanisms of formation and study of the characteristics of complex oxides in the systems calcium - bismuth (lanthanum) — niobium molybdenum (tungsten) - oxygen is very relevant and is in line with current trends in the search for new materials for various functional applications and technologies for their production.

\section{Experimental}

All samples were synthesized using a standard ceramic technique with several heating stages and intermediate grinding after every $50-100^{\circ} \mathrm{C}$ of heating. Initial components were taken in stoichiometric quantities to obtain products according to the equations 1-6:

$$
\begin{gathered}
\mathrm{CaCO}_{3}+\mathrm{R}_{2} \mathrm{O}_{3}+\mathrm{Nb}_{2} \mathrm{O}_{5}+\mathrm{MO}_{3}= \\
=\mathrm{CaRNbMO}_{8}, \\
\mathrm{La}_{2} \mathrm{O}_{3}+\mathrm{Bi}_{2} \mathrm{O}_{3}+\mathrm{Nb}_{2} \mathrm{O}_{5}+\mathrm{WO}_{3}= \\
=\mathrm{La}_{1-\mathrm{x}} \mathrm{Bi}_{\mathrm{x}} \mathrm{Nb}_{1-\mathrm{y}} \mathrm{W}_{\mathrm{y}} \mathrm{O}_{4 \pm \delta}, \\
\mathrm{CaCO}_{3}+\mathrm{R}_{2} \mathrm{O}_{3}+\mathrm{WO}_{3}= \\
=\mathrm{Ca}_{1-\mathrm{u}} \mathrm{R}_{\mathrm{u}} \mathrm{WO}_{4+\delta}, \\
\mathrm{CaCO}+\mathrm{WO}_{3}+\mathrm{Nb}_{2} \mathrm{O}_{5}= \\
=\mathrm{CaW}_{1-\mathrm{z}} \mathrm{Nb}_{\mathrm{z}} \mathrm{O}_{4-\delta}, \\
\mathrm{Bi}_{2} \mathrm{O}_{3}+\mathrm{CaCO}_{3}+\mathrm{Nb}_{2} \mathrm{O}_{5}= \\
=\mathrm{Bi}_{1-\mathrm{v}} \mathrm{Ca}_{\mathrm{v}} \mathrm{NbO}_{4-\delta}, \\
\mathrm{Bi}_{2} \mathrm{O}_{3}+\mathrm{Nb}_{2} \mathrm{O}_{5}+\mathrm{WO}_{3}= \\
=\mathrm{BiNb}_{1-\mathrm{w}} \mathrm{W}_{\mathrm{w}} \mathrm{O}_{4+\delta},
\end{gathered}
$$

where $\mathrm{R}=\mathrm{La}$ or $\mathrm{Bi}, \mathrm{M}=\mathrm{Mo}$ or $\mathrm{W} ; x, y, u$, $z, v, w$ are the quantities of the dopant element.

Stoichiometric amounts of dried precursors were weighed and mixed in an agate mortar as dispersion in ethanol. Powders were heated at $500-1000{ }^{\circ} \mathrm{C}$ (up to $1400{ }^{\circ} \mathrm{C}$ for $\mathrm{LaNb}_{1-\mathrm{y}} \mathrm{W}_{\mathrm{y}} \mathrm{O}_{4+\delta}$ samples) for $\sim 8$ hours at each stage.
The phase composition of the powders was controlled by means of X-ray powder diffraction in the range of $5-75^{\circ}$ of $2 \theta$ (D8 ADVANCE diffractometer (Bruker, Germany), $\mathrm{Cu}$ Ka radiation, $\beta$-filter, PSD VANTEC1). The phase composition and structure of the compounds was examined by comparing XRD patterns with the PDF2 database entries.

Surface morphology and local chemical composition of the powders and ceramic specimens annealed at $1200-1270{ }^{\circ} \mathrm{C}$ were determined by scanning electron microscopy (SEM) using JEOL JSM 6390LA (Jeol, Japan) microscope.

For conductivity measurements the ceramic pellets of $10 \mathrm{~mm}$ in diameter and $2.5 \mathrm{~mm}$ thickness were used. The flat surfaces of pellets were covered with $\mathrm{Pt}$. Impedance spectra were obtained in two-electrode measurement cell on Elins Z-3000 impedance spectrometer, over the frequency ranges $3 \mathrm{MHz}$ to $10 \mathrm{~Hz}$ at stabilized temperatures from $850{ }^{\circ} \mathrm{C}$ to $250{ }^{\circ} \mathrm{C}$ in the cooling run. Impedance spectra were treated with "ZView" software. Using these data, the temperature dependences of electrical conductivity $(\sigma)$ were plotted in Arrhenius coordinates $\lg \sigma-1000 / \mathrm{T}$. 


\section{Results and discussion}

For a series of $\mathrm{Ca}-\mathrm{R}-\mathrm{Nb}-\mathrm{M}-\mathrm{O}$ at a ratio of metal components 1:1:1:1 the analysis of phase formation during the synthesis and search for the proposed single-phase compositions of the $\mathrm{CaRNbMO}_{8}$ type complex oxides was carried out. According to the XRD data, the samples after a series of annealing are not single-phase, but have a variable phase composition throughout the temperature range. In each system, compounds based on complex oxides with the general formula $\mathrm{ABO}_{4}\left(\mathrm{RNbO}_{4}\right.$, $\mathrm{CaMO}_{4}$ ) are predominantly formed. Qualitative change in the phase composition with temperature is presented in Table 1. Thus, the expected compounds of the total composition $\mathrm{CaRNbMO}_{8}$ in the analyzed systems at the applied temperature and time conditions of synthesis were not yet detected.

In the $\mathrm{La}_{1-\mathrm{x}} \mathrm{Bi}_{\mathrm{x}} \mathrm{NbO}_{4}$ series within single-phase regions with increasing bismuth concentration, the lattice is compressed at $x=0.0-0.3$ (monoclinic, SG $I 2 / b$ ) and expands at $x=0.775-1.0$ (triclinic, SG $P$-1). A disproportionately modulated structure was found for the $\mathrm{LaNb}_{1-\mathrm{y}} \mathrm{W}_{\mathrm{y}} \mathrm{O}_{4+\delta}$ solid solutions, previously mentioned by $\mathrm{Li}$ et al. [9] when describing the properties of the $\mathrm{LaNb}_{0.92} \mathrm{~W}_{0.08} \mathrm{O}_{4.04}$ compound. In the present study, after prolonged exposure of samples at $T=1400{ }^{\circ} \mathrm{C}$ (32 hours), additional peaks on the diffraction patterns (see Fig. 1) were detected only for the compositions with $y=0.10$ and above. Solid solutions are formed throughout the studied concentration range, and at $y \leq 0.15$, a mon-

Table 1

Phase composition of $\mathrm{Ca}-\mathrm{R}-\mathrm{Nb}-\mathrm{M}-\mathrm{O}$ systems at different sintering stages

\begin{tabular}{|c|c|c|c|c|}
\hline$T,{ }^{\circ} \mathrm{C}$ & $\begin{aligned} \mathrm{R} & =\mathrm{Bi} \\
\mathrm{M} & =\mathrm{Mo}\end{aligned}$ & $\begin{aligned} \mathrm{R} & =\mathrm{La}, \\
\mathrm{M} & =\mathrm{Mo}\end{aligned}$ & $\begin{array}{l}\mathrm{R}=\mathrm{Bi} \\
\mathrm{M}=\mathrm{W}\end{array}$ & $\begin{array}{l}\mathrm{R}=\mathrm{La} \\
\mathrm{M}=\mathrm{W}\end{array}$ \\
\hline 500 & $\begin{array}{l}\mathrm{CaCO}_{3}, \mathrm{Nb}_{2} \mathrm{O}_{5}, \\
\mathrm{Bi}_{2} \mathrm{MoO}_{6} \\
\mathrm{Bi}_{2} \mathrm{Mo}_{3} \mathrm{O}_{12}\end{array}$ & $\begin{array}{l}\mathrm{CaCO}_{3}, \mathrm{La}_{2} \mathrm{O}_{3}, \\
\mathrm{Nb}_{2} \mathrm{O}_{5}, \mathrm{Mo}_{4} \mathrm{O}_{11}, \\
\mathrm{LaNbO}_{4}, \\
\mathrm{La}_{4} \mathrm{Mo}_{2} \mathrm{O}_{11} \\
\mathrm{La}_{2}\left(\mathrm{MoO}_{4}\right)_{3}, \\
\mathrm{CaMoO}_{4}\end{array}$ & $\begin{array}{l}\mathrm{CaCO}_{3}, \mathrm{Nb}_{2} \mathrm{O}_{5}, \\
\mathrm{WO}_{3}, \mathrm{Bi}_{2} \mathrm{O}_{3}, \\
\mathrm{CaNb}_{2} \mathrm{O}_{6}\end{array}$ & $\begin{array}{l}\mathrm{CaCO}_{3}, \mathrm{WO}_{3}, \\
\mathrm{La}_{2} \mathrm{WO}_{6}, \mathrm{Nb}_{2} \mathrm{O}_{5}, \\
\mathrm{CaWO}_{4}\end{array}$ \\
\hline 600 & $\begin{array}{l}\mathrm{CaCO}_{3}, \mathrm{Nb}_{2} \mathrm{O}_{5}, \\
\mathrm{Bi}_{2} \mathrm{MoO}_{6}, \mathrm{CaMoO}_{4}\end{array}$ & $\begin{array}{l}\mathrm{CaCO}_{3}, \mathrm{Nb}_{2} \mathrm{O}_{5}, \\
\mathrm{La}_{2} \mathrm{Mo}_{2} \mathrm{O}_{9}, \\
\mathrm{CaMoO}_{4}\end{array}$ & $\begin{array}{l}\mathrm{WO}_{3}, \mathrm{Ca}_{3} \mathrm{Bi}_{8} \mathrm{O}_{15}, \\
\mathrm{CaNb}_{2} \mathrm{O}_{6}, \mathrm{CaWO}_{4}\end{array}$ & $\begin{array}{l}\mathrm{WO}_{3}, \mathrm{La}_{2} \mathrm{WO}_{6}, \\
\mathrm{La}_{3} \mathrm{NbO}_{7}, \mathrm{CaWO}_{4}\end{array}$ \\
\hline 700 & $\begin{array}{l}\mathrm{BiNbO}_{4}, \mathrm{Nb}_{2} \mathrm{O}_{5}, \\
\mathrm{Bi}_{2} \mathrm{MoO}_{6}, \mathrm{CaMoO}_{4}\end{array}$ & $\begin{array}{l}\mathrm{CaO}, \mathrm{Nb}_{2} \mathrm{O}_{5}, \\
\mathrm{La}_{2} \mathrm{Mo}_{2} \mathrm{O}_{9}, \\
\mathrm{CaMoO}_{4}, \mathrm{La}_{2} \mathrm{MoO}_{6}\end{array}$ & $\begin{array}{l}\mathrm{BiNbO}_{4}, \mathrm{CaNb}_{2} \mathrm{O}_{6} \\
\mathrm{CaWO}_{4}\end{array}$ & $\begin{array}{l}\mathrm{La}_{2} \mathrm{WO}_{6}, \mathrm{La}_{3} \mathrm{NbO}_{7}, \\
\mathrm{CaWO}_{4}\end{array}$ \\
\hline 800 & $\mathrm{BiNbO}_{4}, \mathrm{CaMoO}_{4}$ & $\begin{array}{l}\mathrm{Nb}_{2} \mathrm{O}_{5}, \mathrm{La}_{3} \mathrm{NbO}_{7} \\
\mathrm{CaMoO}_{4}, \mathrm{La}_{2} \mathrm{MoO}_{6}\end{array}$ & $\mathrm{BiNbO}_{4}, \mathrm{CaWO}_{4}$ & $\begin{array}{l}\mathrm{La}_{2} \mathrm{WO}_{6}, \mathrm{La}_{3} \mathrm{NbO}_{7}, \\
\mathrm{CaWO}_{4}\end{array}$ \\
\hline 900 & $\mathrm{BiNbO}_{4}, \mathrm{CaMoO}_{4}$ & $\begin{array}{l}\mathrm{CaNb}_{2} \mathrm{O}_{6}, \\
\mathrm{La}_{3} \mathrm{NbO}_{7}, \mathrm{CaMoO}_{4}, \\
\mathrm{La}_{2} \mathrm{MoO}_{6}\end{array}$ & $\mathrm{BiNbO}_{4}, \mathrm{CaWO}_{4}$ & $\begin{array}{l}\mathrm{CaNb}_{2} \mathrm{O}_{6}, \\
\mathrm{La}_{3} \mathrm{NbO}_{7}, \mathrm{CaWO}_{4}, \\
\mathrm{La}_{14} \mathrm{~W}_{8} \mathrm{O}_{45}\end{array}$ \\
\hline 1000 & $\mathrm{BiNbO}_{4}, \mathrm{CaMoO}_{4}$ & $\begin{array}{l}\mathrm{CaNb}_{2} \mathrm{O}_{6}, \\
\mathrm{La}_{3} \mathrm{NbO}_{7}, \mathrm{LaNbO}_{4}, \\
\mathrm{CaMoO}_{4}, \mathrm{La}_{2} \mathrm{MoO}_{6}\end{array}$ & $\mathrm{BiNbO}_{4}, \mathrm{CaWO}_{4}$ & $\begin{array}{l}\mathrm{CaNb}_{2} \mathrm{O}_{6}, \mathrm{CaWO}_{4}, \\
\mathrm{La}_{14} \mathrm{~W}_{8} \mathrm{O}_{45}\end{array}$ \\
\hline
\end{tabular}


oclinic phase with a SG $I 2 / b$ is formed; at $\mathrm{y}>0.15$ the tetragonal phase with SG. $I 41 / a$ is formed. Reflections on the diffraction patterns of double substituted samples $\left(\mathrm{La}_{1-\mathrm{x}} \mathrm{Bi}_{\mathrm{x}} \mathrm{Nb}_{1-\mathrm{y}} \mathrm{W}_{\mathrm{y}} \mathrm{O}_{4 \pm \delta}\right)$ correspond to additional phases listed in Table 2.

All samples of $\mathrm{Ca}_{1-\mathrm{u}} \mathrm{Bi}_{\mathrm{u}} \mathrm{WO}_{4+\delta}$ and $\mathrm{CaW}_{1-\mathrm{z}} \mathrm{Nb}_{\mathrm{z}} \mathrm{O}_{4-\delta}$ systems are not singlephase. The main phase in $\mathrm{Ca}_{1-u} \mathrm{R}_{\mathrm{u}} \mathrm{WO}_{4+\delta}$ system is based on calcium tungstate $\mathrm{CaWO}_{4}$ with tetragonal structure (SG I41/a). Homogeneity range of the $\mathrm{Ca}_{1-u} \mathrm{La}_{\mathrm{u}} \mathrm{WO}_{4+\delta}$ solid solution is limited by the La concentration $u=0.0-0.05$. The following phases were additionally detected in $\mathrm{Ca}_{1-u} \mathrm{R}_{\mathrm{u}} \mathrm{WO}_{4+\delta}$ and $\mathrm{CaW}_{1-z} \mathrm{Nb}_{\mathrm{z}} \mathrm{O}_{4-\delta}$ samples with subsequent substitution to a small extent: $\mathrm{La}_{22} \mathrm{~W}_{9} \mathrm{O}_{60}, \mathrm{R}_{2} \mathrm{WO}_{6}, \mathrm{La}_{0.14} \mathrm{WO}_{3}, \mathrm{La}_{2}\left(\mathrm{WO}_{4}\right)_{3}$. In $\mathrm{CaW}_{1-z} \mathrm{Nb}_{z} \mathrm{O}_{4-\delta}$ samples, the second phase of $\mathrm{Ca}_{2} \mathrm{Nb}_{2} \mathrm{O}_{7}$ (monoclinic, SG P21) was found and its concentration increased with the degree of substitution of tungsten in the B-sublattice. The unit cell parameters of the samples were calculated. The values vary slightly within the error of determination (Fig. 2), so the formation of the solid solution even within the range $u=0.0-0.05$ is still under discussion. To resolve this issue, an additional XRD is required with an increase in the exposure time.

The change in the phase composition in the $\mathrm{BiNbO}_{4}$-based system is presented with $\mathrm{BiNb}_{0.95} \mathrm{~W}_{0.05} \mathrm{O}_{4.025}$ and $\mathrm{Bi}_{0.95} \mathrm{Ca}_{0.05} \mathrm{NbO}_{3.975}$ as an example. Tungstencontaining sample at $500{ }^{\circ} \mathrm{C}$, in addition to the initial phases, contains $\mathrm{Bi}_{14} \mathrm{~W}_{2} \mathrm{O}_{27}$ (tetragonal, SG I41/a). An increase in temperature from $700{ }^{\circ} \mathrm{C}$ to $800{ }^{\circ} \mathrm{C}$ leads to the formation of the orthorhom-

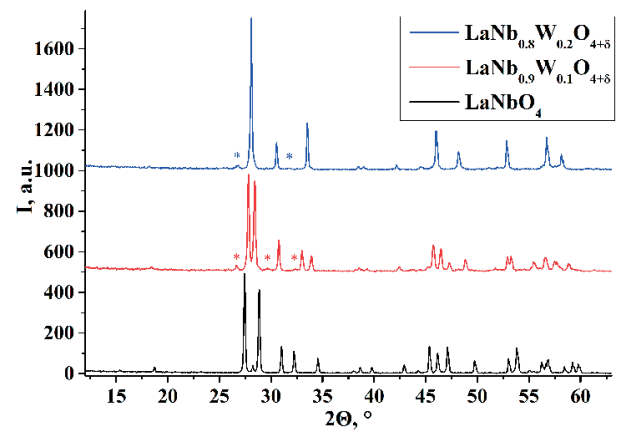

Fig. 1. XRD patterns of samples $\mathrm{LaNb}_{1-\mathrm{y}} \mathrm{W}_{\mathrm{y}} \mathrm{O}_{4+\delta}$ (additional reflections are marked)

Table 2

Phase composition of the $\mathrm{La}_{1-\mathrm{x}} \mathrm{Bi}_{\mathrm{x}} \mathrm{Nb}_{1-\mathrm{y}} \mathrm{W}_{\mathrm{y}} \mathrm{O}_{4+\delta}$ samples

\begin{tabular}{|c|c|c|c|}
\hline Dopant concentration & \multicolumn{3}{|c|}{ Crystal structure } \\
\hline$x=0.1, y=0.1$ & \multirow{10}{*}{$\begin{array}{l}\mathrm{LaNbO}_{4}, \\
\text { monoclinic, } \\
I 2 / b\end{array}$} & $\mathrm{LaNbO}_{4}$, monoclinic, $I 2 / a$ & $\begin{array}{c}\mathrm{La}_{0.33} \mathrm{NbO}_{3} \text {, } \\
\text { orthorhombic, Pmmm }\end{array}$ \\
\hline$x=0.1, y=0.2$ & & $\mathrm{LaNbO}_{4}$, tetragonal, $I 41 / a$ & \\
\hline$x=0.2, y=0.1$ & & $\mathrm{LaNbO}_{4}$, monoclinic, $I 2 / a$ & \multirow{8}{*}{$\begin{array}{c}\mathrm{La}_{0.33} \mathrm{NbO}_{3} \\
\text { orthorhombic, } \\
\text { Pmmm }\end{array}$} \\
\hline$x=0.2, y=0.2$ & & & \\
\hline$x=0.3, y=0.1$ & & & \\
\hline$x=0.3, y=0.2$ & & & \\
\hline$x=0.4, y=0.1$ & & $\mathrm{BiNbO}_{4}$, triclinic, $P-1$ & \\
\hline$x=0.4, y=0.2$ & & $\mathrm{LaNbO}_{4}$, monoclinic, $I 2 / a$ & \\
\hline$x=0.5, y=0.1$ & & $\mathrm{BiNbO}_{4}$, triclinic, $P-1$ & \\
\hline$x=0.5, y=0.2$ & & $\mathrm{LaNbO}_{4}$, monoclinic, $I 2 / a$ & \\
\hline
\end{tabular}


bic phase $\mathrm{BiNbO}_{4}$ (SG Pnna), $\mathrm{Bi}_{5} \mathrm{Nb}_{3} \mathrm{O}_{15}$ (tetragonal, $\mathrm{SG} P 4 / \mathrm{mmm}$ ), $\mathrm{Bi}_{2} \mathrm{WO}_{6}$ (orthorhombic, SG Pcan). At $850^{\circ} \mathrm{C}$ the reflections of $\mathrm{Bi}_{5} \mathrm{Nb}_{3} \mathrm{O}_{15}$ disappear. The calcium-containing sample undergoes changes from the initial composition $\left(\mathrm{Bi}_{2} \mathrm{O}_{3}, \mathrm{Nb}_{2} \mathrm{O}_{5}\right)$ to $\mathrm{BiNbO}_{4}$ (orthorhombic, SG Pnna), $\mathrm{Bi}_{5} \mathrm{Nb}_{3} \mathrm{O}_{15}$ (tetragonal, $\mathrm{SG} P 4 / \mathrm{mmm}$ ), $\mathrm{CaNb}_{2} \mathrm{O}_{6}$ (orthorhombic, SG Pcan). The formation of a new phase $\mathrm{CaBi}_{2} \mathrm{Nb}_{2} \mathrm{O}_{9}$ with orthorhombic structure (SG Pbcn) was found for the compositions $\mathrm{Bi}_{1-v} \mathrm{Ca}_{v} \mathrm{NbO}_{4-\delta}(v=0.15-0.30)$. From the concentration dependence of the unit cell parameters (Fig. 3) it can be seen that a significant change in the lattice parameters occurs when the dopant content increases from 0.00 to 0.05 , which may indicate the formation of a solid solution in this concentration range. Further increase of the $\mathrm{Ca}$ and $\mathrm{W}$ content in the samples practically does not result in any changes in the values of the unit cell parameters.

The particle size of the powdered samples is in the range of 1.0-14 $\mu \mathrm{m}$ (for example $\mathrm{LaNb}_{0.9} \mathrm{~W}_{0.1} \mathrm{O}_{4+\delta}-$ Fig. 4); for the sintered monoclinic briquettes the values increase to $5.0-20 \mu \mathrm{m}$. In the region of tetragonal phase existence, the particle size range of sintered samples is wider

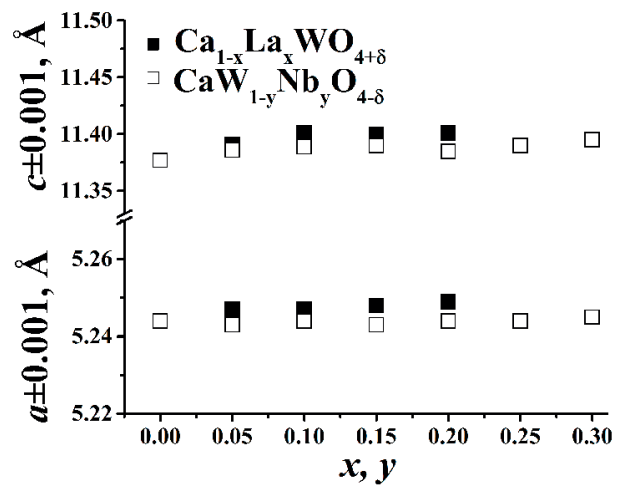

1.0-20 $\mu \mathrm{m}$. The SEM scan (Figs. 4-5) shows that the grains are tightly adjacent to each other only in the monoclinic phase of $\mathrm{LaNb}_{1-\mathrm{y}} \mathrm{W}_{\mathrm{y}} \mathrm{O}_{4+\delta}$ compositions.

The general shape of the temperature dependences of conductivity for $\mathrm{LaNbO}_{4}{ }^{-}$ based samples is linear and is typical for ionic conductors (Figs. 6-9). In addition, small change of slope is seen on the dependencies which may be due to the presence of slight structural phase transitions (at a.c. $600-700^{\circ} \mathrm{C}$ ); these are typical for lanthanum niobate. In bismuth-containing samples conductivity increases within the monoclinic phase existence

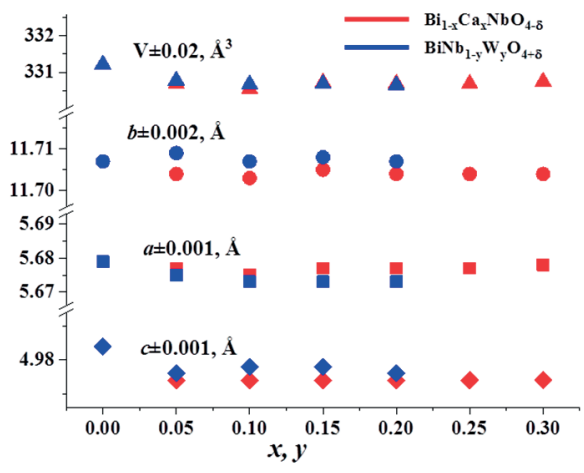

Fig. 3. The unit cell parameters of $\mathrm{BiNbO}_{4}$-based systems calculated in orthorombic structure of $\mathrm{BiNbO}_{4}$ (SG Pnna)

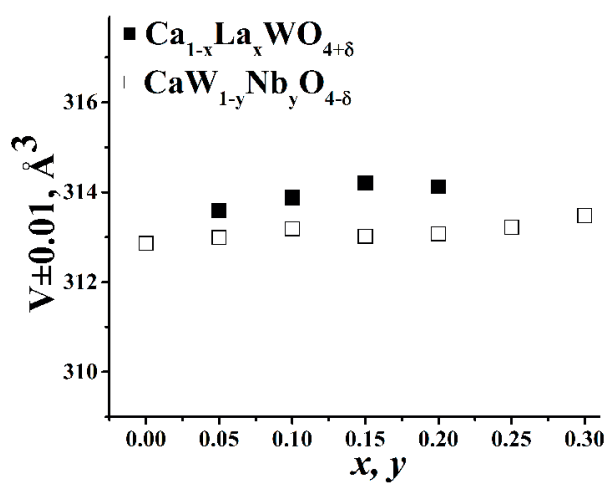

Fig. 2. The unit cell parameters of $\mathrm{Ca}_{1-\mathrm{u}} \mathrm{R}_{\mathrm{u}} \mathrm{WO}_{4+\delta}$ and $\mathrm{CaW}_{1-\mathrm{z}} \mathrm{Nb}_{\mathrm{z}} \mathrm{O}_{4-\delta}$ systems, calculated according to the tetragonal structure of $\mathrm{CaWO}_{4}(\mathrm{SG} I 41 / a)$ 
range and decreases within the triclinic phase with increasing $x$. A similar trend is observed for $\mathrm{LaNb}_{1-\mathrm{y}} \mathrm{W}_{\mathrm{y}} \mathrm{O}_{4+\delta}$ : at $y \leq 0.15$ with increasing dopant concentration,

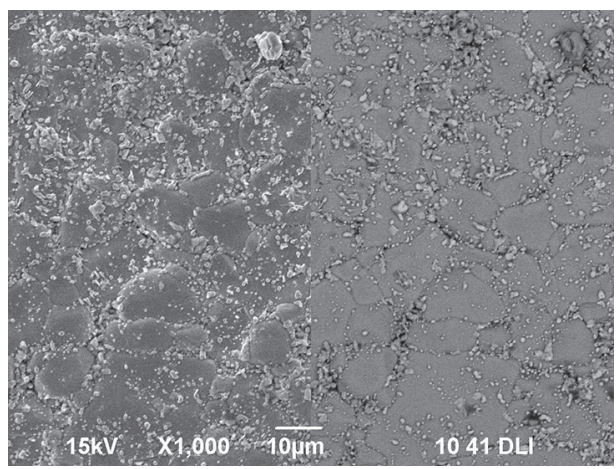

$a$ the conductivity values increase sharply, exceeding those of the parent compound by three orders of magnitude at the maximum point, and then gradually decrease

Fig. 4. Micrographs of the sample $\mathrm{LaNb}_{0.9} \mathrm{~W}_{0.1} \mathrm{O}_{4+\delta}$ obtained by scanning (a) the surface or (b) the cross-section of the briquettes in the secondary (left) and reflected electrons (right)

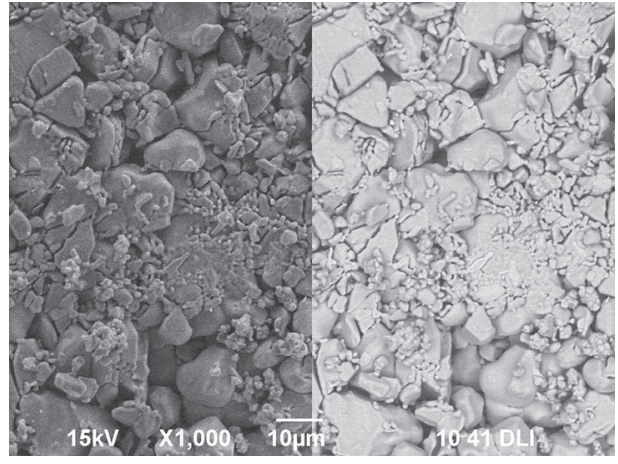

$a$

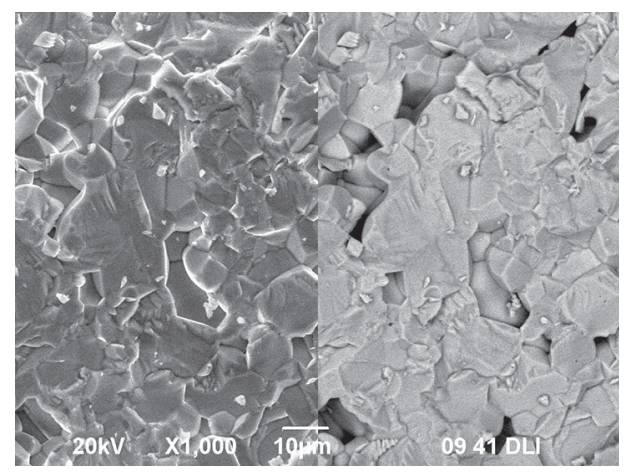

$b$

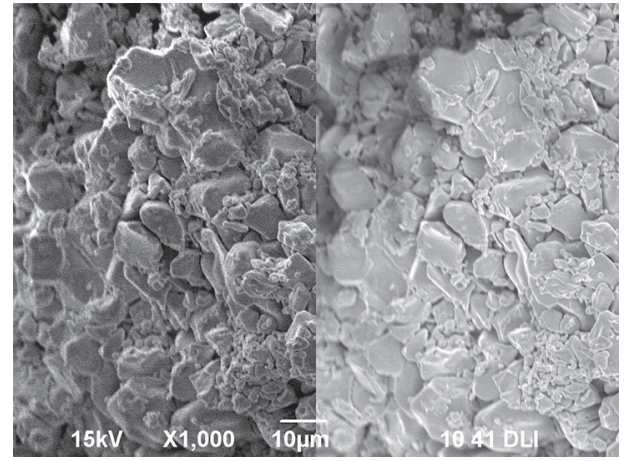

$b$

Fig. 5. Micrographs of the sample $\mathrm{LaNb}_{0.8} \mathrm{~W}_{0.2} \mathrm{O}_{4+\delta}$ obtained by scanning (a) the surface or (b) the cross-section of the briquettes in the secondary (left) and reflected electrons (right)

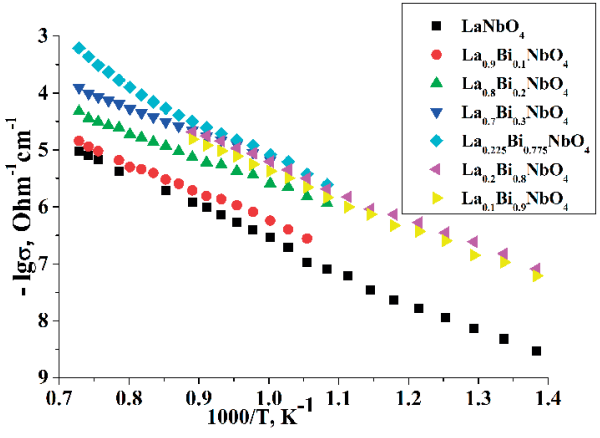

Fig. 6. Temperature dependencies of electrical conductivity $\mathrm{La}_{1-\mathrm{x}} \mathrm{Bi}_{\mathrm{x}} \mathrm{NbO}_{4}$

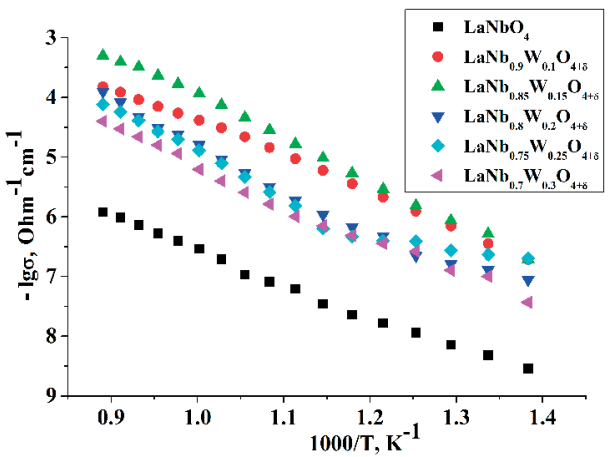

Fig. 7. Temperature dependencies of electrical conductivity $\mathrm{LaNb}_{1-\mathrm{y}} \mathrm{W}_{\mathrm{y}} \mathrm{O}_{4+\delta}$ 


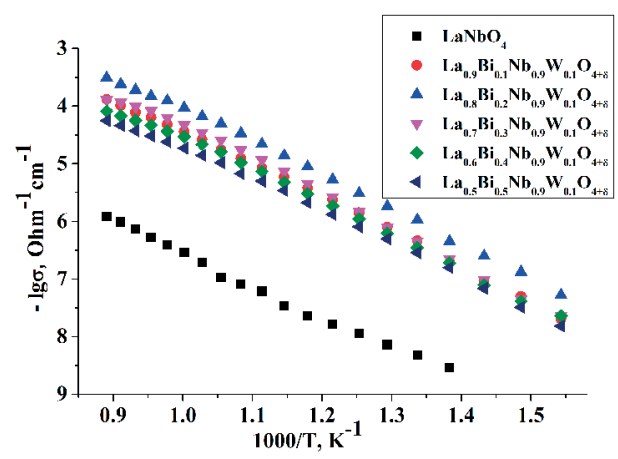

Fig. 8. Temperature dependencies of electrical conductivity $\mathrm{La}_{1-\mathrm{x}} \mathrm{Bi}_{\mathrm{x}} \mathrm{Nb}_{0.9} \mathrm{~W}_{0.1} \mathrm{O}_{4+\delta}$

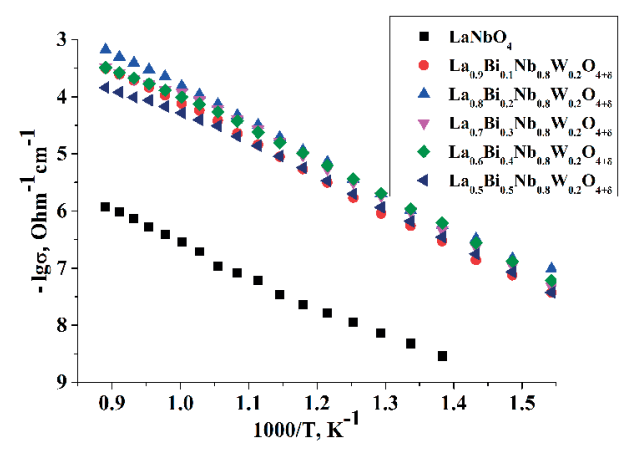

Fig. 9. Temperature dependencies of electrical conductivity $\mathrm{La}_{1-\mathrm{x}} \mathrm{Bi}_{\mathrm{x}} \mathrm{Nb}_{0.8} \mathrm{~W}_{0.2} \mathrm{O}_{4+\delta}$

Activation energy values of samples based on $\mathrm{LaNbO}_{4}$

\begin{tabular}{l|l|l}
\hline Composition & $E_{\mathrm{a}}\left(T_{\text {low }}\right), \mathrm{eV}$ & $E_{\mathrm{a}}\left(T_{\text {hight }}\right), \mathrm{eV}$ \\
\hline $\mathrm{LaNbO}_{4}$ & 0.91 & 1.21 \\
\hline $\mathrm{La}_{0.9} \mathrm{Bi}_{0.1} \mathrm{NbO}_{4}$ & 1.00 & 1.00 \\
\hline $\mathrm{La}_{0.8} \mathrm{Bi}_{0.2} \mathrm{NbO}_{4}$ & 0.88 & 0.88 \\
\hline $\mathrm{La}_{0.7} \mathrm{Bi}_{0.3} \mathrm{NbO}_{4}$ & 1.18 & 0.88 \\
\hline $\mathrm{La}_{0.225} \mathrm{Bi}_{0.775} \mathrm{NbO}_{4}$ & 1.33 & $1.08\left(1.76{ }^{*}\right)$ \\
\hline $\mathrm{La}_{0.2} \mathrm{Bi}_{0.8} \mathrm{NbO}_{4}$ & 0.88 & 1.05 \\
\hline $\mathrm{La}_{0.1} \mathrm{Bi}_{0.9} \mathrm{NbO}_{4}$ & 0.89 & 1.06 \\
\hline $\mathrm{LaNb}_{0.9} \mathrm{~W}_{0.1} \mathrm{O}_{4+\delta}$ & 1.24 & 1.24 \\
\hline $\mathrm{LaNb}_{0.85} \mathrm{~W}_{0.15} \mathrm{O}_{4+\delta}$ & 1.44 & 1.44 \\
\hline $\mathrm{LaNb}_{0.8} \mathrm{~W}_{0.2} \mathrm{O}_{4+\delta}$ & 0.60 & 1.50 \\
\hline $\mathrm{LaNb}_{0.75} \mathrm{~W}_{0.25} \mathrm{O}_{4+\delta}$ & 0.41 & 1.53 \\
\hline $\mathrm{LaNb}_{0.7} \mathrm{~W}_{0.3} \mathrm{O}_{4+\delta}$ & 0.92 & 1.44 \\
\hline $\mathrm{La}_{0.9} \mathrm{Bi}_{0.1} \mathrm{Nb}_{0.9} \mathrm{~W}_{0.1} \mathrm{O}_{4+\delta}$ & 1.28 & 1.10 \\
\hline $\mathrm{La}_{0.8} \mathrm{Bi}_{0.2} \mathrm{Nb}_{0.9} \mathrm{~W}_{0.1} \mathrm{O}_{4+\delta}$ & 1.22 & 1.12 \\
\hline $\mathrm{La}_{0.7} \mathrm{Bi}_{0.3} \mathrm{Nb}_{0.9} \mathrm{~W}_{0.1} \mathrm{O}_{4+\delta}$ & 1.28 & 1.13 \\
\hline $\mathrm{La}_{0.6} \mathrm{Bi}_{0.4} \mathrm{Nb}_{0.9} \mathrm{~W}_{0.1} \mathrm{O}_{4+\delta}$ & 1.28 & 1.08 \\
\hline $\mathrm{La}_{0.5} \mathrm{Bi}_{0.5} \mathrm{Nb}_{0.9} \mathrm{~W}_{0.1} \mathrm{O}_{4+\delta}$ & 1.26 & 1.04 \\
\hline $\mathrm{La}_{0.9} \mathrm{Bi}_{0.1} \mathrm{Nb}_{0.8} \mathrm{~W}_{0.2} \mathrm{O}_{4+\delta}$ & 1.28 & 1.28 \\
\hline $\mathrm{La}_{0.8} \mathrm{Bi}_{0.2} \mathrm{Nb}_{0.8} \mathrm{~W}_{0.2} \mathrm{O}_{4+\delta}$ & 1.25 & 1.25 \\
\hline $\mathrm{La}_{0.7} \mathrm{Bi}_{0.3} \mathrm{Nb}_{0.8} \mathrm{~W}_{0.2} \mathrm{O}_{4+\delta}$ & 1.26 & 1.26 \\
\hline $\mathrm{La}_{0.6} \mathrm{Bi}_{0.4} \mathrm{Nb}_{0.8} \mathrm{~W}_{0.2} \mathrm{O}_{4+\delta}$ & 1.21 & 1.19 \\
\hline $\mathrm{La}_{0.5} \mathrm{Bi}_{0.5} \mathrm{Nb}_{0.8} \mathrm{~W}_{0.2} \mathrm{O}_{4+\delta}$ & 1.21 \\
\hline
\end{tabular}

* The value of $E_{\mathrm{a}}$ in the high-temperature region on the graph of the temperature dependence of the conductivity of the solid solution $\mathrm{La}_{0.225} \mathrm{Bi}_{0.775} \mathrm{NbO}_{4}$. 
within the tetragonal phase. Samples $\mathrm{La}_{1-\mathrm{x}} \mathrm{Bi}_{\mathrm{x}} \mathrm{Nb}_{1-\mathrm{y}} \mathrm{W}_{\mathrm{y}} \mathrm{O}_{4 \pm \delta}$ show high conductivity comparable to the maximum values of the $\mathrm{LaNb}_{1-\mathrm{y}} \mathrm{W}_{\mathrm{y}} \mathrm{O}_{4+\delta}$ conductivity. The activation energy values (Table 3 ) were calculated according to the plots of the conductivity temperature dependencies; the average value is around $1.1 \mathrm{eV}$, which is consistent with the values of activation energies typical for ionic conductors.

In $\mathrm{Ca}_{1-\mathrm{u}} \mathrm{Bi}_{\mathrm{u}} \mathrm{WO}_{4+\delta}$ and $\mathrm{CaW}_{1-\mathrm{z}} \mathrm{Nb}_{\mathrm{z}} \mathrm{O}_{4-\delta}$ series, conductivity increases slightly with increasing dopant concentration. As can be seen in Figs. 10-11 the total conductivity value for all samples is rather low. Therefore, the measurement error in the temperature range below $500{ }^{\circ} \mathrm{C}$ is very large, which does not allow to uniquely determine the values of $-\lg (\sigma)$ for all samples. The values of electrical conductivity of samples $\mathrm{Ca}_{1-\mathrm{u}} \mathrm{Bi}_{\mathrm{u}} \mathrm{WO}_{4+\delta}$ are higher than that of the matrix by no more than one order of magnitude.

\section{Conclusions}

This work demonstrates the processes of phase formation in $\mathrm{Ca}-\mathrm{R}-\mathrm{Nb}$ $\mathrm{M}-\mathrm{O}$. In each system, compounds based on complex oxides of the general formula $\mathrm{ABO}_{4}\left(\mathrm{LaNbO}_{4}, \mathrm{BiNbO}_{4}, \mathrm{CaMO}_{4}\right)$ are predominantly formed. A number

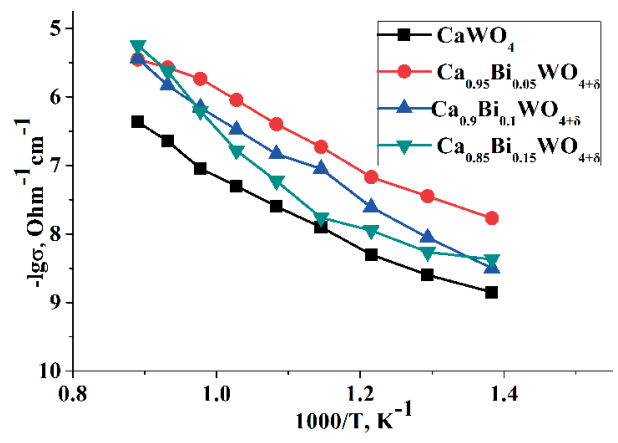

Fig. 10. Temperature dependencies of electrical conductivity $\mathrm{Ca}_{1-\mathrm{z}} \mathrm{Bi}_{\mathrm{z}} \mathrm{WO}_{4+\delta}$
Despite the absence of single-phase samples in the $\mathrm{BiNbO}_{4}$-based series, the conductivity of these compositions as composite materials were evaluated. In comparison with the matrix composition $\mathrm{BiNbO}_{4}\left(\sigma=7.77 \cdot 10^{-7} \mathrm{Ohm}^{-1} \cdot \mathrm{cm}^{-1}\right.$, at $T=800{ }^{\circ} \mathrm{C}$ ) it was possible to increase the conductivity for the sample of the nominal composition $\mathrm{BiNb}_{0.9} \mathrm{~W}_{0.1} \mathrm{O}_{4.05}$ (at $T=800{ }^{\circ} \mathrm{C}$ it is $9.61 \cdot 10^{-6} \mathrm{Ohm}^{-1} \cdot \mathrm{cm}^{-1}$ ). When the temperature decreases to $500{ }^{\circ} \mathrm{C}$, it is possible to observe an equalization of the conductivity values to $8 \cdot 10^{-8} \mathrm{Om}^{-1} \cdot \mathrm{cm}^{-1}$ for all samples containing tungsten.

For calcium doped bismuth niobates, no significant conductivity changes occur. The highest value shows the sample with nominal composition $\mathrm{Bi}_{0.85} \mathrm{Ca}_{0.15} \mathrm{NbO}_{3.925}$ at $\mathrm{T}=800{ }^{\circ} \mathrm{C} \sigma=1.41 \cdot 10^{-6} \mathrm{Ohm}^{-1} \cdot \mathrm{cm}^{-1}$, and the smallest sample of $\mathrm{Bi}_{0.9} \mathrm{Ca}_{0.10} \mathrm{NbO}_{3.95}$ $\sigma=2.71 \cdot 10^{-7} \mathrm{Ohm}^{-1} \cdot \mathrm{cm}^{-1}$ at $\mathrm{T}=800^{\circ} \mathrm{C}$. of samples based on $\mathrm{LaNbO}_{4}, \mathrm{BiNbO}_{4}$, $\mathrm{CaWO}_{4}$ substituted with bismuth, tungsten, calcium, lanthanum and niobium were obtained. Solid solutions are formed in the range $x=0.0-0.3$ and $x=0.775-$ 1.0 for $\mathrm{La}_{1-\mathrm{x}} \mathrm{Bi}_{\mathrm{x}} \mathrm{NbO}_{4}, y=0.0-0.3$ for

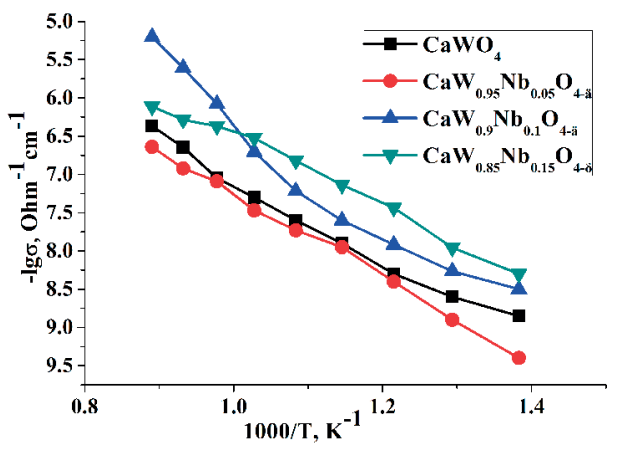

Fig. 11. Temperature dependencies of electrical conductivity $\mathrm{CaW}_{1-y} \mathrm{Nb}_{\mathrm{y}} \mathrm{O}_{4-\delta}$ 
$\mathrm{LaNb}_{1-\mathrm{y}} \mathrm{W}_{\mathrm{y}} \mathrm{O}_{4+\delta}, u=0.0-0.05, z=0.0-0.05$ for $\mathrm{Ca}_{1-\mathrm{u}} \mathrm{La}_{\mathrm{u}} \mathrm{WO}_{4+\delta}$ and $\mathrm{CaW}_{1-\mathrm{z}} \mathrm{Nb}_{z} \mathrm{O}_{4-\delta}$. A significant increase in the conductivity is observed mainly for lanthanum niobates substituted with tungsten.

\section{Acknowledgements}

This work was financially supported by grant of Russian Foundation for Basic Research, project № 18-33-00921.

\section{References}

1. Goodenough JB. Oxide-Ion Electrolytes. Annu Rev Mater Res. 2003;33:91-128. DOI:10.1146/annurev.matsci.33.022802.091651

2. Fergus JW. Electrolytes for solid oxide fuel cells. J Power Sources. 2006;162(1):30-40. DOI:10.1016/j.jpowsour.2006.06.062

3. Malavasi L, Fisher CAJ, Islam MS. Oxide-ion and proton conducting electrolyte materials for clean energy applications: structural and mechanistic features. Chem Soc Rev. 2010;39: 4370-87.

DOI:10.1039/B915141A

4. Orera A, Slater PR. New Chemical Systems for Solid Oxide Fuel Cells. Chem Mater. 2010;22(3):675-90.

DOI:10.1021/cm902687z

5. Haugsrud R, Norby T. Proton conduction in rare-earth ortho-niobates and orthotantalates. Nat Mater. 2006;5:193-6.

DOI:10.1038/nmat1591

6. Cava RJ, Roth RS, Negas T, Parker HS, Minor DB. Crystal Chemistry, Modulated Structure, and Electrical Conductivity in the Oxygen Excess Scheelite-Based Compounds $\mathrm{La}_{1-\mathrm{x}} \mathrm{Th}_{\mathrm{x}} \mathrm{NbO}_{4+\mathrm{x}} / /_{2}$ and $\mathrm{LaNb}_{1-\mathrm{x}} \mathrm{W}_{\mathrm{x}} \mathrm{O}_{4+\mathrm{x}} / \mathrm{I}_{2}$. J Solid State Chem. 1981;40(3):318-29. DOI:10.1016/0022-4596(81)90398-4

7. Vu TD, Barre M, Adil K, Jouanneaux A, Suard E, Goutenoire F. Investigation of the $\mathrm{La}_{2} \mathrm{O}_{3}-\mathrm{Nb}_{2} \mathrm{O}_{5}-\mathrm{WO}_{3}$ ternary phase diagram: Isolation and crystal structure determination of the original $\mathrm{La}_{3} \mathrm{NbWO}_{10}$ material. J Solid State Chem. 2015;229:129-34. DOI:10.1016/j.jssc.2015.05.022

8. Deepa M, Rao PP, Sumi S, Radhakrishnan ANP, Koshy P. New Negative Temperature Coefficient Ceramics in $\mathrm{Ca}-\mathrm{Ce}-\mathrm{Nb}-\mathrm{M}-\mathrm{O}(\mathrm{M}=\mathrm{Mo}$ or W) System. J Am Ceram Soc. 2010;93(6):1576-9.

DOI:10.1111/j.1551-2916.2010.03616.x

9. Li C, Bayliss RD, Skinner SJ. Crystal structure and potential interstitial oxide ion conductivity of $\mathrm{LnNbO}_{4}$ and $\mathrm{LnNb}_{0.92} \mathrm{~W}_{0.08} \mathrm{O}_{4.04}(\mathrm{Ln}=\mathrm{La}, \mathrm{Pr}, \mathrm{Nd})$. Solid State Ionics. 2014;262:530-5.

DOI:10.1016/j.ssi.2013.12.023 